J. Dairy Sci. 100:7750-7750

https://doi.org/10.3168/jds.2017-100-9-7750

(c) American Dairy Science Association ${ }^{\circledR}, 2017$.

\title{
Corrigendum to "Heritability and genome-wide association mapping for supernumerary teats in French Alpine and Saanen dairy goats" (J. Dairy Sci. 99:8891-8900)
}

Pauline Martin, Isabelle Palhière, Gwenola Tosser-Klopp, and Rachel Rupp

In the Acknowledgments section (page 8899), the authors neglected to acknowledge funding for a doctoral research grant. The following statement should be included with the Acknowledgments: "Pauline Martin received a doctoral research grant from "Région Midi-Pyrénées", Animal Genetics Department from INRA, and GENOMCAP research program, including INRA, APIS-GENE, ALLICE (formerly UNCEIA), CAPGENES and FCEL."

The authors regret the errors.

\section{REFERENCES}

Martin, P., I. Palhière, G. Tosser-Klopp, and R. Rupp. 2016. Heritability and genome-wide association mapping for supernumerary teats in French Alpine and Saanen dairy goats. J. Dairy Sci. 99(11):8891-8900. https://doi.org/10.3168/jds.2016-11210. 